\title{
POSISI DAN PERAN MEDIA DALAM KEHIDUPAN MASYARAKAT
}

\author{
Husnul Khatimah \\ Mahasiswa Pasca UIN Sunan Gunung Diati \\ Email: husnul14khatimah@gmail.com
}

\begin{abstract}
Mass media has an important position in people's lives, so mass media is placed as mass communication which acts as a communicator and agent of change, being a pioneer of change in the public environment that can influence audiences through messages such as information, entertainment, education and other messages and accessible to the public at large. As a form of the importance of media can be seen from the influence felt by the public, starting from the cognitive, effective, to conative aspects of the mass media and the negative-positive impact of social media. Even though the position and role of the media are very important, the community must also be careful with media remember that the nature of the media is so flexible. Negative values of the role of the media in Indonesia can occur either from the mass media or social media, so there needs to be attention from each party, both from the media manager to the community itself. The participation of several parties in paying attention to the media is expected to filter out negative things that might occur.
\end{abstract}

Key Words:

Position, Role, Mass Media, Society 


\begin{abstract}
Abstrak
Media Massa memiliki posisi yang penting dalam kehidupan masyarakat, sehingga media massa ditempatkan sebagai komunikasi massa yang berperan sebagai komunikator serta agen of change, menjadi pelopor perubahan dalam lingkungan publik yang dapat mempengaruhi khalayak melalui pesan berupa informasi, hiburan, pendidikan maupun pesan-pesan lainnya dan dapat dijangkau masyarakat secara luas. Sebagai bentuk dari pentingnya media dapat dilihat dari pengaruh yang dirasakan oleh khalayak, mulai dari aspek kognitif, afektif, hingga konatif dari media massa dan dampak positif negatif dari media sosial.Walaupun posisi dan peran media sangat penting akan tetapi masyarakat juga harus berhati-hati dengan media mengingat bahwa sifat media yang begitu fleksibel. Nilai negatif atas peranan media di Indonesia bisa saja terjadi baik dari media massa ataupun media sosial, sehingga perlu adanya perhatian dari setiap pihak, baik dari pengelola media hingga masyarakat itu sendiri. Keikutsertaan beberapa pihak dalam memperhatikan media diharapkan dapat menyaring halhal negatif yang mungkin dapat terjadi.
\end{abstract}

\title{
Kata Kunci:
}

Posisi, Peran, Media Massa, Masyarakat 


\section{A. Pendahuluan}

Media merupakan sarana komunikasi bagi masyarakat, yang terletak di antara dua pihak sebagai perantara atau penghubung. ${ }^{116}$ Sedangkan McLuhan bersama Quentin Fiore, menyatakan bahwa "media setiap zamannya menjadi esensi masyarakat" hal ini menunjukkan bahwasanya masyarakat dan media selalu berkaitan dan media menjadi bagian yang penting dalam kehidupan masyarakat, sadar atau tidak sadar bahwa media memiliki pengaruh yang berdampak positif maupun negatif dalam pola dan tingkah laku masyarakat. ${ }^{117}$

Media massa meliputi media cetak, media elektronik dan media online. Media cetak terbagi menjadi beberapa macam diantaranya seperti koran, majalah, buku, dan sebagainya, begitupula dengan media elektronik terbagi menjadi dua macam, diantaranya radio dan televisi, sedangkan media online meliputi media internet seperti website, dan lainnya. ${ }^{118}$

Jika dilihat dari kemampuannya menarik perhatian manusia (masyarakat), ketiga jenis media massa tersebut sama-sama memiliki strategi dalam menarik perhatian khalayak. Mengenai menarik perhatian masyarakat, media sosial yang merupakan bagian dari media online bisa saja lebih aktif dalam mengalihkan perhatian masyarakat dari media massa dan hanya tertuju pada media sosial. ${ }^{119}$

\footnotetext{
116 Risa Agustin, Kamus Lengkap Bahasa Indonesia ( Surabaya: Serba Jaya, 2011), 413.

117 McLuhan M \& Quentin Fiore, The Medium is The Massage (New York: Bantam Books, 1967), 464

${ }^{118}$ Syarifuddin Yunus, Jurnalistik Terapan (Bogor: Ghalia Indonesia, 2010), 27

119 Dan Zarrella, The Social Media Marketing Book (Jakarta: PT Serambi Ilmu Semesta Anggota IKAPI, 2010), 2-3
} 
Pada dasarnya media sosial merupakan perkembangan mutakhir dari teknologiteknologi web baru berbasis internet yang memudahkan semua orang untuk dapat berkomunikasi, berpartisipasi, saling berbagi dan membentuk sebuah jaringan secara online, sehingga dapat menyebarluaskan konten mereka sendiri. Post di blog, tweeter, youtube dapat diproduksi dan dapat dilihat secara langsung oleh jutaan orang secara gratis.

Berdasarkan pengertian media sosial di atas dapat diartikan bahwa semua orang bebas menyampaikan pendapat, saling melempar komentar, menyebar berbagai informasi. Media sosial tidak memiliki pengawas yang mengawasi berbagai macam media sosial dalam melakukan interaksi.

Berbeda dengan media sosial, media massa memiliki pengawas misalnya pengawas media penyiaran yang dikenal dengan sebutan Kemenkominfo yang bertugas mengatur alokasi frekuensi, dan Komisi Penyiaran Indonesia (KPI) dengan berbagai undang-undang yang telah tercantum dalam buku Pedoman Perilaku Penyiaran dan Standar Program Siaran (P3SPS) berfungsi mengawasi hal-hal mengenai penyiaran terutama isi siaran. Kemudian media cetak yang diawasi oleh Dewan Pers (pengawas), dan media online (website) diawasi oleh Satuan Tugas (Satgas) berdasarkan undang-undang yang dibentuk oleh Dewan Pers. Bahkan pada website jika dilihat dari aspek legalnya harus berbadan hukum atau memiliki izin 
dari pihak-pihak terkait. ${ }^{120}$ dikarenakan wesbsite berbasis media online lebih ditujukan kepada produk jurnalisme berupa pemberitaan bukan sekedar informasi.

Berdasarkan pemaparan di atas maka posisi dan peran media dalam kehidupan manusia menarik untuk dikaji dalam tulisan ini.

\section{B. Posisi Media dalam Kehidupan Manusia}

Posisi media menjadi penting seiring dengan hadirnya banyak media di tengah masyarakat. Kehadiran media tidak dapat dipisahkan dari kehidupan masyarakat baik di daerah perkotaan maupun pedesaan. Kondisi dari setiap media dewasa ini, terutama setelah hadirnya media sosial sangat memperluas cakupan komunikasi manusia. Untuk lebih jelasnya tentang posisi media, berikut penjelasannya.

Pertama, Media Cetak. Koran, sekian tahun lalu keberadaan koran dianggap segera berakhir. Jika dapat bertahan setelah adanya televisi, koran dinilai tidak akan banyak berpengaruh lagi. Pandangan ini memiliki alasan, karena banyak koran di kota-kota besar terpaksa gulung tikar. Namun sejak 1970-an, koran terbukti mampu bertahan, meskipun prosesnya memang tidak mudah. Sekalipun sebagian koran terbesar gagal bertahan, koran-koran yang mampu menyajikan pelayanan baru, khususnya di daerah pinggir kota berhasil menyelamatkan diri. Majalah, sama halnya dengan koran, majalah juga harus berusaha keras menyesuaikan diri dengan kondisi-kondisi baru. Majalah yang mampu bertahan umumnya adalah yang bersifat

\footnotetext{
${ }^{120}$ Lewanmeru, Ini Peringatan Dewan Pers Bagi Media Online di Indonesia. PosKupang.com.http://kupang.tribunnews.com./amp/2018/08/29/ini-peringatan-dewan-pers-bagimedia-online-di-indonesia
} 
khusus, misalnya majalah khusus wisata, olahraga, hobi perahu layar, penggemar acara televisi atau berita-berita ilmiah.

Kedua, Media Siran. Radio semakin terdesak oleh televisi, namun masih memiliki banyak penggemar. Kecendrungannya adalah jangkauan siaran radio semakin sempit sehingga yang paling mampu bertahan adalah radio-radio yang hanya melayani suatu wilayah kecil saja. Tantangannya tidak kalah dari yang dihadapi oleh koran dan majalah, namun radio terbantu oleh penemuan transistor yang membuatnya jauh lebih ringkas. ${ }^{121}$

Selain radio, media siaran juga terdiri dari televisi. Televisi merupakan media baru setelah hadirnya radio. Masyarakat lebih menikmati acara yang disiarkan oleh televisi dibandingkan media lainnya sebab dengan televisi, masyarakat dapat melihat dan mendengar perstiwa yang disampaikan. Berdasarkan dua jenis media massa tersebut setiap media memiliki sejarah dan karakteristik yang berbeda sehingga baik media cetak ataupun siaran sangat dibutuhkan sebagai sarana komunikasi massa. Perkembangan media massa tentu saja mengalami pasang surut, namun para pengelola media tidak tinggal diam ketika media yang dikelola mengalami penurunan peminat, karena semakin berkembanganya suatu teknologi dan kemampuan manusia dalam menciptakan inovasi untuk berkomunikasi, kini selain media cetak dan media siaran, produk media massa pun berkembang pada media online.

\footnotetext{
${ }^{121}$ Rivers L. W, dkk., Media Massa \& Masyarakat Modern. Terjemahan, Haris Munandar dan Dudy Priatna (Jakarta: Prenada Media Group, 2008), 20-21.
} 
Menurut Ashadi Siregar sebagaimana dikutip oleh Agung Kurniawan, media online dapat diartikan sebagai sebutan umum untuk sebuah bentuk media yang berbasis telekomunikasi dan multimedia (komputer dan internet). Di dalamnya terdapat portal berita, website (situs web), radio online, televisi online, pers online, dan lain sebagainya, dengan karakteristik masing-masing sesuai dengan fasilitas yang memungkinkan pengguna atau konsumen memanfaatkannya. ${ }^{122}$

Keberadaan media online dapat memudahkan masyarakat menikmati suatu informasi ataupun berita serta hiburan melalui internet. Internet merupakan jenis media massa baru dan populer di Indonesia pada tahun $1996 .^{123}$ Saat ini di Indonesia media cetak seperti koran telah memiliki alamat website resmi sehingga memudahkan para pembaca untuk menikmati berita yang tertulis di koran tanpa harus membeli koran. Alamat website bukan hanya dimiliki atau dibuat oleh suatu lembaga yang bergerak di dalam penyiaran informasi melainkan dibuat juga oleh orang perorang atau suatu lembaga lain yang membutuhkan website sebagai penyalur informasi mengenai lembaganya kepada publik, misalnya website suatu universitas, kantor kementerian agama dan lain sebagainya. Kemudian media siaran, radio dan televisi. Berbagai radio dan televisi swasta kini telah menjajahkan diri di dunia online guna menyampaikan pesan kepada khalayak yang kemungkinan tidak sempat menikmati isi siaran melalui radio dan televisi secara langsung.

\footnotetext{
122Agung Kurniawan., Transformasi Pelayanan Publik (Yogyakarta: Pembaruan, 2005), 20.

${ }^{123}$ Ma'ruf Amir, Etika Komunikasi Massa dalam Pandangan Islam (Jakarta: PT Logos Wacana Ilmu, 1999), 29.
} 
Sejak awal khalayak media adalah masyarakat luas secara keseluruhan, bukan hanya kalangan tertentu. Pengelola media di Indonesia hingga kini masih terus mengembangkan kemampuannya dalam upaya menghadapi dunia baru dan menyediakan program-program unggulan yang sesuai dengan kebutuhan masyarakat, serta dapat bersaing satu sama lain.

Di samping media massa, media sosial yang merupakan salah satu jenis media online juga turut hadir dalam kehidupan masyarakat. Media sosial lebih dominan sebagai sarana interaksi dan penyalur informasi. Dewasa ini, media sosial yang sering digunakan oleh masyarakat sebagai berikut; (1) WhatsApp (WA) sebagai sarana interaksi dengan anggota yang nomor WAnya telah diketahui terlebih dahulu dan dapat melihat story (tulisan, foto, video) apabila nomor kedua orang yang melakukan interaksi telah disimpan pada kontak HP. (2) Facebook (FB) merupakan media komunikasi yang cakupannya lebih luas dari WA, dan anggotanya dapat dicari sesuai dengan nama FB. Melalui FB seseorang dapat menulis sesuatu yang panjang atau pendek yang disebut status, upload foto dan video. (3) Instagram (IG), media ini mirip dengan FB yang memiliki cakupan luas dan anggotanya dapat dicari sesuai dengan nama IGnya. Pengguna IG lebih sering mengupload foto atau video beserta caption dibanding dengan hanya mengupload tulisan dikarenakan kapasitasnya yang terbatas. Berbeda dengan WA, melalui FB dan IG pengguna dapat mengintip beranda atau status seseorang tanpa harus menambah ataupun mengonfirmasi pertemanan terlebih dahulu namun berbeda halnya apabila ada beberapa pengguna IG sengaja mengunci berandanya sehingga orang yang tidak 
mengikutinya tidak dapat melihat. Selain media sosial tersebut, masih banyak media lainnya, tetapi yang lebih sering digunakan adalah tiga media tersebut.

Kebutuhan setiap masyarakat pada berbagai media berbeda-beda sehingga media memiliki posisi yang berbeda pula di kalangan masyarakat. Media cetak menjadi media yang penting dikalangan orang dewasa khususnya bapak-bapak. Media cetak yang masih bertahan hingga saat ini adalah koran sedangkan majalah sudah tidak lagi terlihat. Begitu pentingnya koran bahkan beberapa dari kalangan tersebut sengaja berlangganan koran untuk mendapatkan informasi dan berita hangat. Halaman yang sering diincar oleh pembaca koran adalah halaman yang membahas politik, ekonomi, olahraga dan kolom lowongan pekerjaan. Bagi masyarakat yang menyukai berbagai hal berkaitan dengan politik akan memfokuskan diri untuk membaca koran dengan subjudul politik. Begitupun dengan subjudul lainnya. Sama halnya dengan informasi lowongan pekerjaan, iklan lowongan pekerjaan ini sangat dibutuhkan oleh masyarakat yang belum mendapatkan pekerjaan tetap.

Media siaran, pada media ini khalayaknya mulai dari anak-anak hingga dewasa. Radio biasanya dinikmati oleh masyarakat ketika sedang dalam perjalanan. Misalnya di dalam mobil, agar tidak bosan para pengemudi seringkali menyalakan radio untuk mendengar musik, informasi dan berita sehingga tidak hanya mendapatkan hiburan melainkan juga informasi dan berita. Kemudian Televisi yang memiliki banyak saluran siaran sehingga dapat dipilih oleh khalayak sesuai kebutuhan masing-masing. Setiap saluran memiliki posisi yang berbeda pada setiap khalayak. Saluran siaran yang dominan menayangkan berita akan mendapatkan 
posisi penting bagi orang dewasa (ibu-ibu dan khususnya bapak-bapak), dengan menonton berita seseorang lebih mengetahui tentang informasi serta kondisi dunia khususnya Indonesia baik dari segi politik, ekonomi, kriminal, bencana alam dan lain sebagainya. Saluran pendidikan, khalayak yang menyukai saluran ini biasanya merupakan dari kalangan ibu-ibu. Pada acara fokus islami yang disiarkan oleh TVRI NTB misalnya, khalayak yang menonton acara tersebut dominan adalah ibu-ibu. Kemudian saluran yang dominan menayangkan acara hiburan akan disukai oleh ibu-ibu, para remaja serta anak-anak.

Media online, pada media online ini biasanya digemari oleh seluruh kalangan baik dewasa, remaja maupun anak-anak. Beberapa contoh penggunaan media online ini misalnya ketika berada di luar rumah dan tidak bisa menonton televisi, di situlah peran televisi online sebagai media online berfungsi sehingga kedudukan atau posisinya menjadi penting bagi masyarakat. Selain itu misalnya bagi remaja, sebelum memasuki dunia perkuliahan, calon mahasiswa akan mencari informasi mengenai universitas yang diminatinya melalui website.

Media sosial berada di posisi tertinggi dalam kehidupan masyarakat karena sering digunakan ketika berkomunikasi dan digunakan oleh seluruh kalangan. Selain digunakan untuk berkomunikasi biasa juga dapat digunakan untuk berjualan. Misalnya seseorang yang berjualan pakaian, dapat mempromosikan barangnya melalui WA, FB, IG atau jenis lainnya. Melalui media sosial juga seseorang dapat berdialog mengenai lowongan pekerjaan. Berbagai media dengan bantuan internet digemari karena alatnya yang Canggih, jika dulu internet hanya dapat diakses 
melalui komputer, kini internet telah dapat diakses melalui handphone sehingga lebih mudah dibawa kemana-mana.

\section{Peran Media dalam Kehidupan Manusia}

Media massa merupakan sarana komunikasi massa yang berperan sebagai komunikator serta agen of change yakni pelopor perubahan dalam lingkungan publik yang dapat mempengaruhi khalayak melalui pesan berupa informasi, hiburan, pendidikan maupun pesan-pesan lainnya dan dapat dijangkau masyarakat secara luas. Dewasa ini, di era globalisasi yang semakin cepat, peran media massa dalam kehidupan manusia sehari-hari tidak dapat dihindari lagi. Mengingat bahwa posisi media massa dalam kehidupan masyarakat begitu penting maka kesuksesan media massa dalam menjalankan perannya sebagai komunikator dapat dilihat dari semakin berkembangnya media massa, bertahannya media massa hingga saat ini, dan semakin bertambahnya stasiun, perusahaan hingga website dan program yang disuguhkan oleh pengelola media cetak dan media elektronik. Media massa tidak akan bertahan hingga saat ini apabila tidak ada masyarakat yang menggunakan atau memanfaatkannya dalam kehidupan, karena bagaimanapun media massa tergantung pada banyaknya pemirsa.

Apabila dilihat secara menyeluruh, menurut McQuail terdapat 6 (enam) perspektif dalam melihat peran media massa dalam kehidupan sosial terutama dalam masyarakat modern, antara lain :

1. Melihat media massa sebagai window on event and experience. Media dipandang sebagai jendela yang memungkinkan khalayak melihat apa 
yang sedang terjadi di luar sana, atau media merupakan sarana informasi untuk mengetahui berbagai peristiwa.

2. Media sering dianggap sebagai a mirror of event in socity and the world, implying a faithful reflection. Cermin berbagai peristiwa yang ada di masyarakat dan dunia, yang merefleksikan apa adanya, karenanya para pengelola media sering merasa tidak bersalah jika media penuh dengan kekerasan, konflik, pornografi dan berbagai keburukan lain.

3. Memandang media massa sebagai filter, atau gatekeeper yang menyeleksi berbagai hal untuk diberi perhatian atau tidak. Televisi senantiasa memilih isu, informasi atau bentuk content yang lain berdasarkan standar para pengelolanya.

4. Media massa sering dipandang sebagai guide, penunjuk jalan atau interpreter, yang menerjemahkan dan menunjukkan arah atas berbagai ketidakpastian, atau alternatif yang beragam.

5. Melihat media massa sebagai forum untuk mempresentasikan berbagai informasi dan ide-ide kepada khalayak, sehingga memungkinkan tejadinya tanggapan dan umpan balik.

6. Media massa sebagai interlocutor, yang tidak hanya sekedar tempat berlalu lalangnya informasi, tetapi juga partner komunikasi yang memungkinkan terjadinya komunikasi interaktif. ${ }^{124}$

Tidak jauh berbeda dengan peran media massa itu sendiri, perspektif dalam melihat peran media menurut McQuail di atas pada dasarnya ingin menunjukan

${ }^{124}$ Denis McQuail, Mass Communication Theory (London: Sage Publication, 2000), 66. 
bahwa peran media dalam kehidupan sosial bukan hanya sebagai sarana hiburan atau pelepas ketegangan, melainkan isi dan informasi yang disajikan mempunyai peran yang signifikan dalam proses sosial. Peran yang signifikan ini seperti yang telah dijelaskan sebelumnya bahwa media massa berperan mempengaruhi masyarakat melalui beberapa konten, salah satunya adalah pendidikan. Dalam konten pendidikan, media massa mencoba memberikan pencerahan, mencerdaskan dan meluaskan wawasan pendengar, penonton dan pembacanya. Misalnya dalam konteks politik, media massa memberikan pendidikan politik, menyadarkan khalayak akan hak dan kewajiban sebagai warga Negara, dan juga bisa lebih mengenal pemimpin atau calon presiden dan calon wakil presiden melalui debat yang disiarkan.

Isi siaran media massa merupakan konsumsi otak bagi masyarakat, sehingga apa yang ada di media massa akan mempengaruhi realitas subjektif pelaku interaksi sosial, dikarenakan media adalah mata manusia untuk melihat dunia. Hal ini menunjukan peran aktif media dalam menyajikan informasi kepada khalayak, penyajiannya dengan menggunakan teori agenda setting, di mana teori agenda setting menurut Maxwell McCombs dan Donal Shaw adalah "mass media have the ability to transfer the salience of items on their news agendas to the public agenda. We judge as important what the media judge as important" (media massa memiliki kemampuan memindahkan hal-hal penting dari agenda berita mereka menjadi agenda publik. Kita menilai penting apa saja yang dinilai penting oleh media).

Gambaran tentang realitas yang dibentuk oleh isi media massa inilah yang kemudian akan mendasari respon dan sikap khalayak terhadap berbagai objek 
sosial. Kesalahan dalam proses pemberitaan akan membuat audience menerima pesan yang tidak lengkap, sehingga menimbulkan gambaran yang salah pula terhadap objek sosial, oleh karenanya media massa dituntut menyampaikan informasi secara akurat dan berkualitas.

Peran media massa juga tidak bisa terlepas dari fungsi media massa itu sendiri. Ketika menjalankan perannya, media massa harus memperhatikan dan mengingat fungsinya. Berdasarkan UU Nomor 40 Tahun 1999 tentang pers, media massa berfungsi untuk menginformasikan, mendidik, menghibur, dan pengawasan sosial (social control)-pengawas perilaku publik dan penguasa.

Keberhasilan media massa dalam berperan sebagai agen of change dapat dilihat dari pengaruh media massa terhadap individu dan masyarakat. Media tidak hanya dapat mempengaruhi apa yang seseorang telah ketehui melainkan juga mempengaruhi bagaiamana seseorang belajar tentang dunianya dan berinteraksi satu sama lain. Pengaruh media massa meliputi tiga aspek; Pertama, aspek kognitif, yang artinya dari tidak tahu menjadi tahu. Contohnya seseorang yang berada di dalam rumah tidak akan mengetahui sesuatu peristiwa yang terjadi di luar, namun dengan adanya media massa seseorang menjadi tahu peristiwa yang sedang atau telah terjadi di luar rumah, luar daerah, bahkan luar negeri. Seperti gempa di Lombok yang terjadi beberapa bulan yang lalu, seseorang yang berada di Bandung tidak akan tahu mengenai gempa di Lombok jika tidak disiarkan melalui media massa, melalui media massa, seseorang memperoleh informasi tentang benda, orang atau tempat yang belum pernah dikunjungi secara langsung. 
Kedua, aspek afektif yang berarti dari tidak suka menjadi suka. Pada aspek ini juga dapat meningkatkan atau menurunkan dukungan moral. Contoh dari efek afektif ini seperti iklan peralatan make up yang ada di televisi ataupun internet, seorang wanita yang awalnya tidak menyukai riasan akan tergoda dengan iklaniklan yang ditayangkan di televisi dan internet karena melihat aktrisnya yang cantik, dan gaya bahasa yang digunakan sehingga ada hasrat ingin membeli dan memakainya agar dapat terlihat cantik seperti aktris produk tersebut.

Ketiga, aspek konatif yaitu merubah sikap dan perilaku. Media massa sangat berperan dalam perkembangan bahkan perubahan tingkah laku suatu masyarakat, oleh karena itu kedudukan media massa sangat penting. Perubahan sikap dan perilaku ini seperti anak-anak yang menyukai film Upin dan Ipin, dengan menonton dan mendalami karakter Upin dan Ipin yang sopan, ceria dan rajin beribadah, maka secara tidak langsung hal tersebut mengajarkan pada anak untuk berperilaku sepeti itu. Melalui tayangan Upin dan Ipin beberapa anakpun rajin beribadah. Selain merubah sikap menjadi lebih baik, media massa juga merubah budaya suatu masyarakat seperti yang telah dijelaskan sebelumnya dalam peran media massa.

Kemudian media sosial telah berhasil mentransformasi praktik komunikasi searah media siaran dari satu institusi media ke banyak audiens menjadi praktik komunikasi dialogis antara banyak audiens. Peran media sosial dalam kehidupan manusia yakni sebagai alat berdialog atau interaksi antar manusia dengan menggunakan internet dan teknologi web. untuk menjaga tali silaturahmi, saling tukar informasi dan lain sebagainya, namun dewasa ini masyarakat Indonesia pada khususnya telah 
salah memperlakukan media sosial di mana para netizen (penggua media sosial) menyebarkan berita baik yang benar maupun yang hoax.

Sama halnya dengan media massa, media sosial juga memiliki dampak kepada masyarakat yang merupakan hasil dari peran media sosial, antara lain; (1) dampak positif yakni mempererat silahturahmi, menyediakan ruang untuk berpesan positif seperti melakukan dakwah agama, mengakrabkan hubungan pertemanan di kala seseorang malu berteman di dunia nyata, menyediakan informasi yang tepat dan akurat seperti informasi lowongan pekerjaan, beasiswa dan sebagainya, menambah wawasan dan pengetahuan seperti pengetahuan praktisi. (2) dampak negatif yaitu penipuan, menimbulkan rasa malas belajar, pornografi, bebas berbahasa.

\section{Penutup}

Media memiliki posisi yang penting dalam kehidupan masyarakat. Setiap jenis media memiliki khalayak yang setia. Media yang dominan membahas berita sering dimanfaatkan oleh orang dewasa. Media yang lebih dominan membahas informasi dan hiburan memiliki posisi yang penting dikalangan ibu-ibu, remaja serta anakanak. Media online memiliki khalayak yang netral dari kalangan dewasa hingga anak-anak.

Peran media dalam kehidupan sehari-hari yakni sebagai komunikator serta agen of change dan sarana interaksi. Media memiliki peran yang sangat penting sehingga posisi media masapun menjadi penting dalam masyarakat. Sebagai bentuk dari pentingnya media dapat dilihat dari pengaruh yang dirasakan oleh khalayak, mulai 
dari aspek kognitif, afektif, hingga konatif dari media massa dan dampak positif negative dari media sosial.

Walaupun posisi dan peran media sangat penting akan tetapi masyarakat juga harus berhati-hati dengan media mengingat bahwa sifat media yang begitu fleksibel. Nilai negatif atas peranan media di Indonesia bisa saja terjadi baik dari media massa ataupun media sosial, sehingga perlu adanya perhatian dari setiap pihak, baik dari pengelola media hingga masyarakat itu sendiri. Keikutsertaan beberapa pihak dalam memperhatikan media diharapkan dapat menyaring hal-hal negatif yang mungkin dapat terjadi. 


\section{Daftar Pustaka}

Agustin, Risa, Kamus Lengkap Bahasa Indonesia. Surabaya: Serba Jaya, 2011.

Amir, Ma'ruf, Etika Komunikasi Massa dalam Pandangan Islam. Jakarta: PT Logos Wacana Ilmu, 1999.

Kurniawan, Agung, Transformasi Pelayanan Publik. Yogyakarta: Pembaruan, 2005

Lewanmeru, Ini Peringatan Dewan Pers Bagi Media Online di Indonesia. PosKupang.com.http://kupang.tribunnews.com./amp/2018/08/29/iniperingatan-dewan-pers-bagi-media-online-di-indonesia. (29/08/2018)

McLuhan, M., \& Quentin Fiore, The Medium is The Massage. New York: Bantam Books, 1967.

McQuail, Denis, Mass Communication Theory. London: Sage Publication, 2000.

Rivers L. W, dkk., Media Massa \& Masyarakat Modern. Terjemahan, Massa Media and Modern Society, Oleh Haris Munandar dan Dudy Priatna. Jakarta: Prenada Media Group, 2008.

Yunus, Syarifuddin, Jurnalistik Terapan, Bogor: Ghalia Indonesia, 2010

Zarrella, Dan, The Social Media Marketing Book. Jakarta: PT Serambi Ilmu Semesta Anggota IKAPI, 2010. 


\section{Petunjuk Penulisan}

Tasâmuh menerima tulisan dalam bentuk artikel dan laporan penelitian, baik yang menggunakan bahasa Indonesia, Inggris, maupun Arab, dengan ketentuan sebagai berikut:

1. Tulisan tersebut belum pernah diterbitkan atau dipublikasikan dalam suatu jurnal berkala atau buku.

2. Topik tulisan berkisar pada kajian-kajian yang berkaitan dengan ilmu dakwah dan Komunikasi.

3. Judul tulisan maksimal 14 kata.

4. Semua tulisan harus menyertakan abstrak (100-150 kata) dan kata kunci (3-7 kata).

5. Jumlah halaman antara 15-20 nomor halaman dengan ukuran kwarto spasi ganda dengan menggunakan jenis huruf Futura $\mathrm{Lt} \mathrm{B} \dagger$ dan besar hurup 12 pt.

6. Setiap kata Arab yang belum resmi terbakukan dalam bahasa Indonesia ditulis mengikuti pedoman transliterasi yang ditetapkan dan cara penulisannya dimiringkan (italic), hal ini juga berlaku untuk kata-kata asing yang lain (seperti bahasa Inggris dan bahasa Daerah) dan cara penulisannya dimiringkan (italic),

7. Transliterasi tidak berlaku untuk nama orang, tempat, institusi, dan sejenisnya.

8. Penulis menyerahkan file beserta print out naskahnya.

9. Semua tulisan menggunakan referensi model footnote dengan teknik penulisan sebagai berikut: Nama Penulis, Judul Buku Yang Ditulis Miring (Kota Penerbit: Nama Penerbit, Tahun Terbit), Nomor Halaman. Sebagai contoh:

a. Buku atau Kitab:

- John Lewis Coser, The Function of Social Conflict (New York: Free Press, 1969), 125. 
- Sofian Effendi, Membangun Martabat Manusia Dalam Perspektif Islam (Yogakarta: UGM Press, 2005), 24.

- Ibnu Jarir al-Thabari, Jami' al-Bayan, Jilid 9 (Beirut: Dar alKutub Ilmiyah, 1992), 67.

b. Buku Terjemahan:

David Hill, Pengembangan dan Pemberdayaan Masyarakat, ter. Adam Hulaimi, Jilid 2 (Jakarta: Pustaka Pelajar, 1997), 127.

c. Artikel dalam Buku atau Ensiklopedi:

- Nurcholis Majid, "Cendekiawan dan Penguatan Civil Society di Indonesia" dalam Peran Cendekiawan Muslim Dalam Menegakkan Hak Politik Civil Society, ed. Tim Editor Masika (Jogjakarta: Bintang Budaya, 1996), 124.

- D.S. Adam, "Theology," Encyclopedia of Religion and Ethics, ed. James Hastings, Jilid 4 (New York: Charles Scribner's Sons, tt), 293.

d. Artikel dalam Jurnal:

Faisal Ismail, "On Developing Liberation Theology in Islam," dalam Jurnal Gazwatul Fikri, Vol. 9 No. 2 (Yogyakarta: Fakultas Dakwah UIN Sunan Kalijaga, Desember 1999), 165.

e. Artikel dalam Media Massa:

Fawaizul Umam, "Quo Vadis Kebebasan Beragama di Indonesia", dalam Koran KOMPAS, Edisi 30 Maret 2001, 4.

f. Kitab Suci:

QS. al-Qashash (28): 5. Perjanjian Baru, Yoh ( 20): 31.

g. Bila mengutip ulang referensi yang sama secara berurut, maka cukup tulis: Ibid. Jika halamannya berbeda, cukup tambahkan nomor halamannya: Ibid., 14.

h. Bila referensi terkutip ulang berselang oleh satu atau lebih referensi berbeda, maka cukup tulis last name pengarang berikut satu kata awal judul dari referensi dimaksud. Misalnya, Zahrah, Ushûl..., 35. 
10. Selain mencantumkan footnote, penulis juga harus mencantumkan DAFTAR PUSTAKA dengan aturan penulisan diurutkan secara alfabetis. Nama penulis diketik dengan mendahulukan nama marga atau nama akhir jika nama penulis terdiri dari 2 kata atau lebih, judul buku atau nama jurnal maupun nama media massa ditulis miring (Kota Penerbit: Lembaga Penerbit, Tahun Terbit) tanpa diakhiri tanda titik.

Contoh:

a. Buku: Nasution, Harun, Perkembangan Pemikiran Cendikiawan Muslim Indonesia (Jakarta: Dunia Ilmu, 1998)

b. Jurnal: Ismail, Faisal, "On Developing Liberation Theology in Islam," dalam Jurnal Gazwatul Fikri, Vol. 9 No.2 (Yogyakarta: Fakultas Dakwah UIN Sunan Kalijaga, Desember 1999)

c. Media massa: Umam, Fawaizul, "Quo Vadis Kebebasan Beragama di Indonesia", dalam Koran KOMPAS, Edisi 30 Maret 2001

d. Makalah: Akbar, Muhammad, "Membangun Paradigma Baru Fakultas Dakwah", dalam Makalah Seminar Pengembangan Fakultas Dakwah di Indonesia, Mataram, 3 Maret 2004 